\title{
Profile of wound healing process induced by allantoin ${ }^{1}$
}

\author{
Perfil do processo de cicatrização induzido pela alantoína
}

\author{
Lorena Ulhôa AraújoI, Andrea Grabe-Guimarães" ${ }^{\mathrm{II}}$, Vanessa Carla Furtado Mosqueira ${ }^{\mathrm{II}}$, Claudia Martins Carneiro ${ }^{\mathrm{II}}$, Neila \\ Márcia Silva-Barcellos ${ }^{\text {II }}$
}

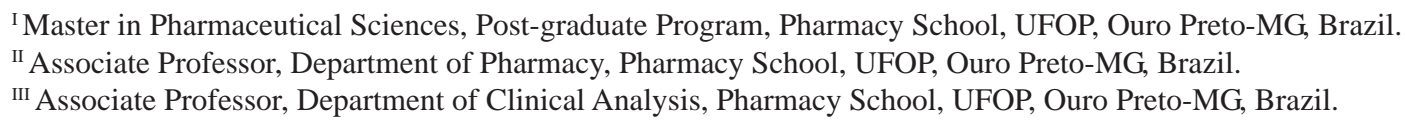

\section{ABSTRACT}

Purpose: To evaluate and characterize the wound healing process profile induced by allantoin incorporated in soft lotion oil/water emulsion using the planimetric and histological methods. Methods: Female Wistar rats ( $\mathrm{n}=60)$ were randomly assigned to 3 experimental groups: (C) control group-without treatment; (E) group treated with soft lotion O/W emulsion excipients; (EA) group treated with soft lotion $\mathrm{O} / \mathrm{W}$ emulsion containing allantoin 5\%. The emulsions either containing or not allantoin were topically administered for 14 days and the wound area was evaluated by planimetry and by qualitative and quantitative histological analysis of open wound model. Results: The data which were obtained and analyzed innovate by demonstrating, qualitatively and quantitatively, by histological analysis, the profile of healing process induced by allantoin. The results suggest that the wound healing mechanism induced by allantoin occurs via the regulation of inflammatory response and stimulus to fibroblastic proliferation and extracellular matrix synthesis. Conclusion: This work show, for the first time, the histological wound healing profile induced by allantoin in rats and demonstrated that it is able to ameliorate and fasten the reestablishment of the normal skin.

Key words: Wound Healing. Allantoin. Histology. Animal Experimentation. Rats.

\section{RESUMO}

Objetivo: Avaliar e caracterizar o perfil cicatricial induzido pela alantoína incorporada em uma emulsão óleo/água, sob os aspectos planimétrico e histológico. Métodos: Ratos Wistar fêmeas $(n=60)$ foram agrupados aleatoriamente em três grupos experimentais grupo controle - sem tratamento (C); grupo tratado com emulsão pura (E); grupo tratado com emulsão contendo 5\% de alantoína (EA). As emulsões contendo ou não alantoína foram administradas topicamente durante 14 dias e a área da ferida foi avaliada por planimetria e por análise histológica qualitativa e quantitativa em modelo de ferida aberta. Resultados: Na análise planimétrica não foi observado diferenças significativas entre os grupos experimentais. Os resultados da análise histológica sugerem que o mecanismo de cicatrização induzido pela alantoína ocorre via controle da resposta inflamatória e estímulos à proliferação fibroblástica e síntese de matrix extracelular de maneira mais intensa e rapidamente em relação aos grupos controles. Conclusão: Este trabalho mostra pela primeira vez o perfil histológico de cicatrização induzido pela alantoína em ratos, demonstrando ser capaz de melhorar e acelerar o processo de reconstituição da pele.

Descritores: Cicatrização de Feridas. Alantoína. Histologia. Experimentação Animal. Ratos.

${ }^{1}$ Research performed at the Post-graduate Program in Pharmaceutical Sciences, Pharmacy School, Ouro Preto Federal University (UFOP), Minas Gerais, Brazil.

\section{Introduction}

Wound healing is a physiological process which restores the skin integrity, aiming to repair the damaged tissues ${ }^{1,2}$. This process starts with the hemostasis and proceeds in three interrelated dynamic and overlapping phases: inflammation, proliferation and remodeling ${ }^{1,3-5}$. The evolution of these phases involves events of cellular migration and transmigration, vasoconstriction, vasodilatation, angiogenesis, formation of granulation tissue and deposition of extracellular matrix.
The allantoin (Figure 1), 5-ureide-hydantoin, has been widely cited in literature as holder of numerous pharmacological activities, among them: wound healing ${ }^{6,7}$, anti-irritating, hydrating and remover of necrotic tissue ${ }^{6}$, stimulating the cell mitosis ${ }^{8}$; as well as promoter of epithelial stimulation, analgesic action ${ }^{9}$ and keratolytic activity ${ }^{10}$. For all these reports, the allantoin has been used in cosmetic and pharmaceutical preparations for over 70 years with different therapeutic purposes and especially as a 
wound healing booster. However, despite this broad description and therapeutic application, surprisingly enough, there are no data that support these pharmacodynamic actions, and the allantoin action mechanism is still unknown ${ }^{11}$.

In this context, the aim of this study was to evaluate and describe the wound healing process profile induced by allantoin incorporated in soft lotion oil/water emulsion using planimetric and histological analysis. For this purpose an in vivo wound rat model was used and the macro and microscopic contractions of treated lesions were evaluated.

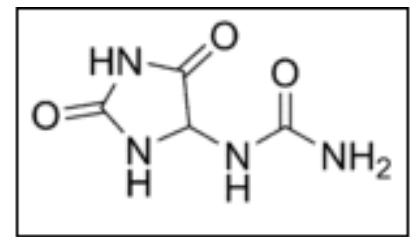

FIGURE 1 - Allantoin structure: 5-ureidohydantoin

\section{Methods}

Solvents and reagents

Allantoin was purchased from Sigma-Aldrich ${ }^{\circledR}$ (Italy); methylparben and propylparaben were provided by Synth ${ }^{\circledR}$ (Brazil); cetostearyl alcohol and sodium cetilstearilsulfate were purchased from Natural Pharma ${ }^{\circledR}$ (Brazil); ethylic alcohol, mineral oil and sorbitol solution 70\% were purchased by Tedia ${ }^{\circledR}$ (USA). Water was purified by Milli-Q system from Millipore (USA).

\section{Pharmaceutical formulating}

The Table 1 shows the composition of soft lotion oil/water $(\mathrm{O} / \mathrm{W})$ emulsion pharmaceutical formulation used as vehicle for allantoin.

TABLE 1 - Composition (w/w) of soft lotion O/W emulsion

\begin{tabular}{c|c}
\hline Components & Soft lotion O/W emulsion \\
\hline Methylparaben & $0,10 \mathrm{~g}$ \\
\hline Propylparaben & $0,15 \mathrm{~g}$ \\
\hline Ethilic alcohol & $2,0 \mathrm{~mL}$ \\
\hline Cetostearyl alcohol & $3,6 \mathrm{~g}$ \\
\hline Sodium \\
Cetilestearilsulfato & $0,4 \mathrm{~g}$ \\
\hline Mineral oil & \\
\hline Sorbitol solution $70 \% \mathrm{w} / \mathrm{v}$ & $4,0 \mathrm{~mL}$ \\
\hline Allantoin & $5,0 \mathrm{~mL}$ \\
\hline Water & $5,0 \mathrm{~g}$ \\
\hline
\end{tabular}

\section{Animals}

Sixty healthy female Wistar rats (180-200g) obtained from Ouro Preto Federal University (UFOP) were used in all studies. The experimental protocol was approved by the Ethical Committee of UFOP (number 2007/98) and was in agreement with the Guide for the Care and Use of Laboratory Animals, published by the US National Institute of Health (NIH Publication, revised in 1985). All the experimental procedures were in conformity with the rules of the Brazilian College for Animal Experimentation (COBEA). The animals were housed in standard individual polypropylene cages in a room and were maintained in an alternating 12 hours light-dark cycle with a standard pellet diet (Labcil Petilizado-Socil, Brazil) and purified drinking water ad libitum during the period of acclimatization (7 days) and throughout the experimental period.

\section{Experimental groups}

The animals were randomly distributed into three groups: (C) control group-without treatment; (E) group treated with soft lotion $\mathrm{O} / \mathrm{W}$ emulsion excipients; (EA) group treated with soft lotion $\mathrm{O} / \mathrm{W}$ emulsion containing allantoin 5\%.

\section{Experimental open wound model}

The animals were anesthetized by intraperitoneal injection of sodium pentobarbital $(50 \mathrm{mg} / \mathrm{Kg})$ and after the anesthesia had reached the necessary depth, trichotomy of the dorsal back of each animal was carried out and an excision of about $1 \mathrm{~cm}^{2}$ was made by removing a full thickness piece of the skin (epidermis and dermis), as described by Sekine et al. ${ }^{12}$, exposing the dorsal fascia muscle (Figure 2). The treatment, which started soon after the wound was produced, consisted of applying $0.25 \mathrm{~g}$ of each topical formulation. In $\mathrm{C}$ group no topical application was performed, and it was considered a negative control.

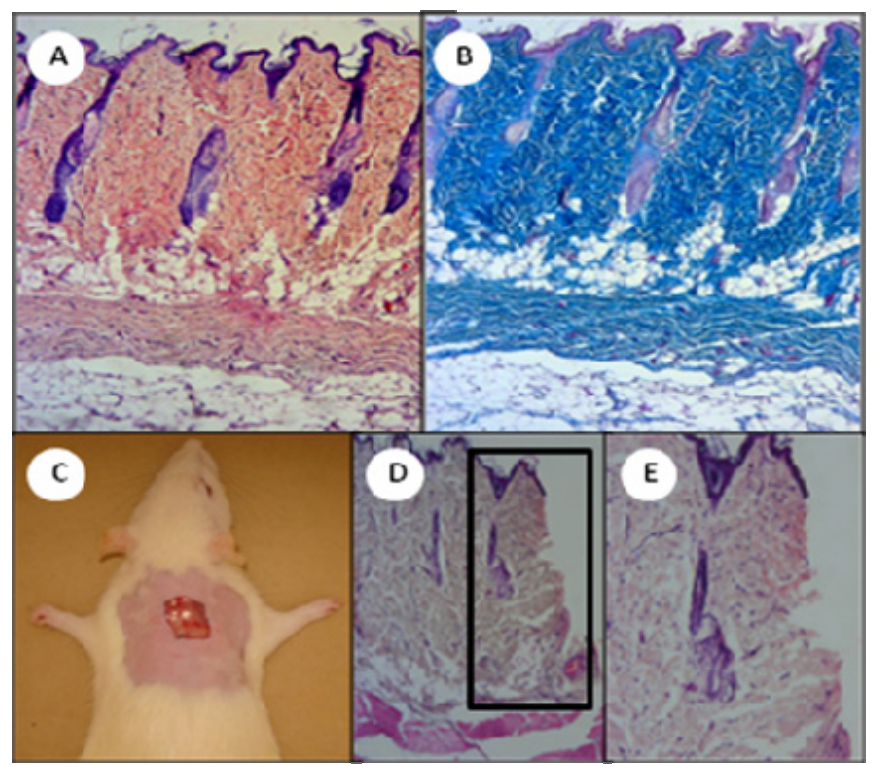

FIGURE 2 - A and B: Histological appearance of the normal rat skin (A: Hematoxylin-Eosin and B: Masson's trichrome); C: Open wound; $\mathbf{D}$ and $\mathbf{E}$ : Histological appearance of the skin after the wound and removed from the skin and dermis (D) and depth of the wound area $(\mathbf{E})$ 


\section{Planimetric analysis}

The size of lesions was determined using the planimetric method, projecting the lesion onto a transparent pattern foil on 0 , 3rd, 7th and 14th days. The images were transposed to a computer and analyzed using the software AutoCad ${ }^{\circledR}$ 2006. The wound contraction rate was measured as percentage reduction in wound size. Wound contraction (WC) was calculated from the area determinations as follows ${ }^{13}$ :

$\mathrm{WC}=\frac{\left(\text { Area } \mathrm{D}_{0}-\text { Area } \mathrm{D}_{t}\right) \times 100}{\text { Area } \mathrm{D}_{0}}$ where $t=3,7$ and 14 days.

\section{Histological analysis}

\section{Collection and preparation of the biological material}

After sacrifice, using overdose of sodium pentobarbital (100 mg/kg), the wounds of animals were excised on the 3rd, 7th, 14th, 21st and 28th days after the surgery, containing a margin of normal skin around the edges of the wound. Then, the tissues were preserved in $10 \%$ buffered formalin until the proceedings. $4 \mu \mathrm{m}$ thickness sections were stained with Hematoxylin-Eosin and with Masson Trichrome. The cuts were analyzed microscopically by the same pathologist without prior knowledge of the identification of the groups.

\section{Qualitative analysis}

In order to characterize qualitatively the wound healing process induced by allantoin, the tissue parameters, epithelialization, congestion, inflammatory process, presence or absence of necrosis and tissue neoformation, were analyzed by optical microscopy (Olympus CH30, Japan) on the 3rd, 7th, 14th, 21st and 28th days after the surgery. The histological parameters were classified according to the intensity of occurrence in five levels (- absence; + discrete; ++ moderate; +++ intense; ++++ very intense).

\section{Quantitative analysis (Morphometry)}

The quantitative analysis was performed using scans of the tissues to quantify the inflammatory process and neoformation of collagen induced by allantoin. All cellular nucleus and collagen fibers in the skin fragments were quantified in 20 randomly fields (total covered area equal to $1.5 \times 10^{6} \mu^{2}$ ). The images were amplified, acquired by a Microcamera Leica and the software DM5000B Leica Application Suite (Version 2.4.0 R1 Leica Microsystems, Switzerland Ltd) and analyzed by Leica Software QWin V3 (Leica Microsystems, Switzerland Ltd).

\section{Analysis statistics}

The data of planimetric and histological analysis were presented as mean \pm S.E.M. and statistical evaluation was performed by ANOVA and Tukey post-test. Values lower than $\mathrm{P}<0.05$ were considered significant. All analyzes were performed using the GraphPad Prism 4.0 Software (Prism software, Irvine, CA, USA).

\section{Results}

\section{Planimetric analysis}

The planimetry evaluation (Figure 3) of the wound contraction showed gradual reduction of wound area in all experimental groups as time passed, except for some animals, which presented an increase of the wound size on the 3rd day of analysis. It was observed that only at this time (3rd day) there was a significant difference in the wound contraction from untreated group (C) and the group treated with allantoin (EA).

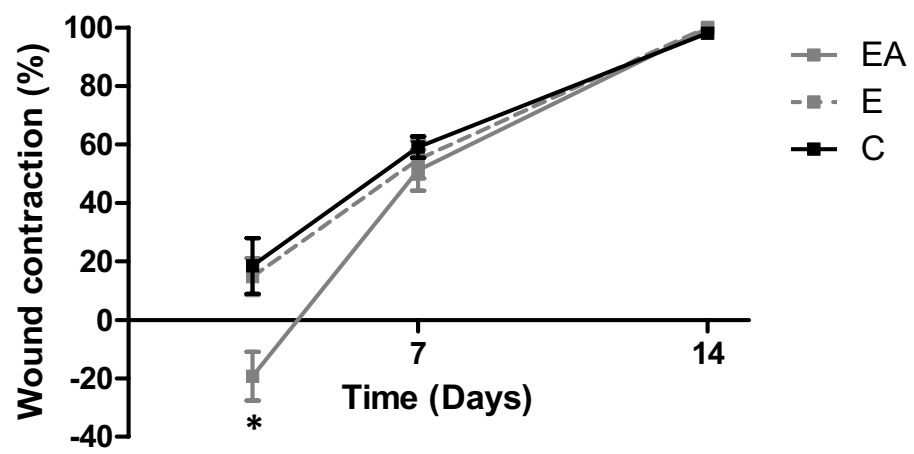

FIGURE 3 - Kinetic of the percentage of wound contraction in the untreated (C) and treated animals with soft lotion O/W emulsion containing (EA) or not allantoin (E) in the times on 3rd, 7th and 14th days. Results were expressed as mean \pm S.E.M. $(* p \leq 0.05)$

\section{Histological analysis}

\section{Qualitative analysis}

In general, similar wound healing histological pattern was observed with the treatment with soft lotion $\mathrm{O} / \mathrm{W}$ emulsion containing (EA) or not (E) allantoin or in the animals untreated (C) (Figure 4). On the 3rd post-operative day (Figure 4: A, B, G, H, $\mathrm{M}$ and $\mathrm{N}$ ) an inflammatory process was observed, presenting congestion, hyperemia, necrosis, inflammatory cells, some collagen deposition and absence of epithelium. On the 7th day, there was still the presence of the congestion characteristic of the 3rd day, although with less intensity. The inflammatory process was more intense and diffused, with great presence of inflammatory cells, and intense necrosis. It was also observed the presence of new blood vessels (angiogenesis) and a greater amount of fibroblasts, that induced a greater collagen neoformation (fibers were more numerous and more mature-looking) compared to 3rd day. Additionally, fibrin-leukocyte crusts were present in the wounds in all groups evaluated. On the 14th day (Figure 4: C, D, I, J, O and $\mathrm{P})$ the wound healing process was advanced, presenting reduction of the inflammatory process characterized by a smaller amount of inflammatory cells, discrete inflammatory infiltrated and absence of necrosis, reepithelization of the tissues and collagen deposition presenting more differentiate fibers. On the 21st day, the wound 
healing process was more advanced, with small amount of inflammatory cells and completely reconstructed epithelium. The granulation tissue was formed, characterized by intense collagen deposition (numerous and many mature aspect fibers). Additionally, on the 28th day (Figure 4: E, F, K, L, Q and R) intense collagen deposition was observed, characterizing a fully formed scar tissue and the tissue morphology was more similar to a normal state.

When comparing the wound healing process induced by the three groups studied (C, E and EA), it was observed that, despite having similar profiles as described above, they differ on the intensity and speed of occurrence of the three phases of wound healing (inflammatory, fibroplasia and maturation), as seen in Table 2, which presents the intensity of histological parameters and Figure 4 which shows photomicrographs of induced wound healing.
The results obtained indicated that the treatment with soft lotion $\mathrm{O} / \mathrm{W}$ emulsion containing or not allantoin had a positive effect on the wound healing process, due to the epithelial stimulation (14th day), congestion (3rd, 7th and 14th day), inflammation reduction (3rd, 14th and 21st) and also collagen deposition stimulation (14th, 21st and 28th day), as can be observed in Table 2 and in Figure 4. However, the group treated with allantoin (EA) induced a reduction of inflammatory cells and stimulated the collagen deposition early, already on 3rd post-operative day (Figure 4: $\mathrm{M}$ and $\mathrm{N}$ ). On the 14th day, the treated groups ( $\mathrm{E}$ and EA) presented greater collagen deposition, with more organized tissue observed in the EA group (Figure 4: $\mathrm{O}$ and $\mathrm{P}$ ). And, finally on the 28th day, it was observed that the treatment with allantoin induced to a more organized tissue, close to a healthy skin (Figure 4: Q and R).

TABLE 2 - Intensity of histological parameters assessed in untreated animals (C) and treated with soft lotion O/W emulsion containing (EA) or not (E) allantoin

\begin{tabular}{|c|c|c|c|c|c|c|}
\hline & & \multicolumn{5}{|c|}{ Histological Parameters } \\
\hline Groups & Days & Epithelialization & Congestion & Inflammation & Necrosis & Collagen \\
\hline \multirow{5}{*}{$\mathbf{C}$} & 3 & - & ++++ & +++ & ++ & - \\
\hline & 7 & - & +++ & +++ & +++ & + \\
\hline & 14 & + & + & ++ & - & ++ \\
\hline & 21 & ++ & - & ++ & - & ++ \\
\hline & 28 & ++ & - & - & - & ++ \\
\hline \multirow{5}{*}{$\mathbf{E}$} & 3 & - & ++ & ++ & ++ & + \\
\hline & 7 & - & ++ & +++ & +++ & ++ \\
\hline & 14 & ++ & - & + & - & +++ \\
\hline & 21 & ++ & - & - & - & +++ \\
\hline & 28 & ++ & - & - & - & +++ \\
\hline \multirow{5}{*}{ EA } & 3 & - & ++ & ++ & ++ & + \\
\hline & 7 & - & ++ & ++ & +++ & ++ \\
\hline & 14 & ++ & - & + & - & +++ \\
\hline & 21 & ++ & - & - & - & +++ \\
\hline & 28 & ++ & - & - & - & ++++ \\
\hline
\end{tabular}

Classification of histological parameters according to the intensity of occurrence: - absence; + discrete; ++ moderate; +++ intense; ++++ very intense. 


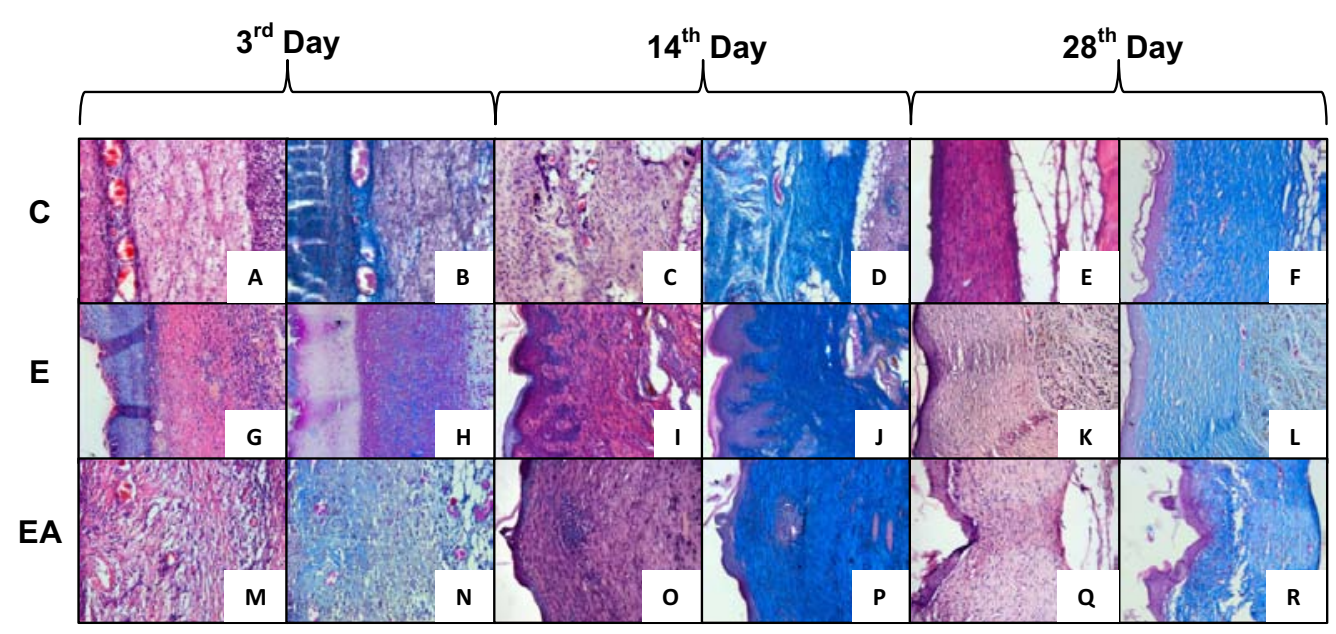

FIGURE 4 - Photomicrographs of the skin of rats not treated and treated with soft lotion O/W emulsion containing or not allantoin in the times of 3rd (A, B, G, H, M, N), 14th (C, D, I, J, O, P) and 28th (E, F, K, L, Q, R) day. Hematoxilina - Eosine (A, C, E, G, I, K, M, O, Q) and Masson's Tricromic (B, D, F, H, J, L, N, P, R).

\section{Quantitative analysis}

The inflammatory process (Figure 5A) analyzed by counting the cell number in the injured tissue were similar between the $\mathrm{C}$ and $\mathrm{EA}$ groups, although the $\mathrm{C}$ group presented the more intense inflammatory process. On the other hand, the E group demonstrated an inflammatory peak on the 7th day, which differentiated this group among the others. The processes of synthesis, degradation and remodeling of collagen (Figure 5B) analyzed by the determination of the collagen occupied area were similar in all groups studied (C, E and EA), although, as previously described, with variable intensities. In the untreated group (C) the inflammatory profile was characterized by a high amount of inflammatory cells on 3rd, 7th, 14th and 21st, falling on the 28th day (Figure 5A). The EA group demonstrated the best wound healing activity, because the allantoin incorporated into emulsion induced a reduction of inflammatory cells on the 7th day, in contrast with the inflammatory peak of the control groups and mainly due to the significant reduction of inflammatory cell number on the 21st day (Figure 5A).

Moreover, the results about collagen content demonstrated that it increased after the 3rd post-operative day and remained in a constant level after 14th day. The collagen deposition, mainly after the 14th day, was higher in the EA group on the qualitative analysis, although significant differences were not observed (Figure 5B).

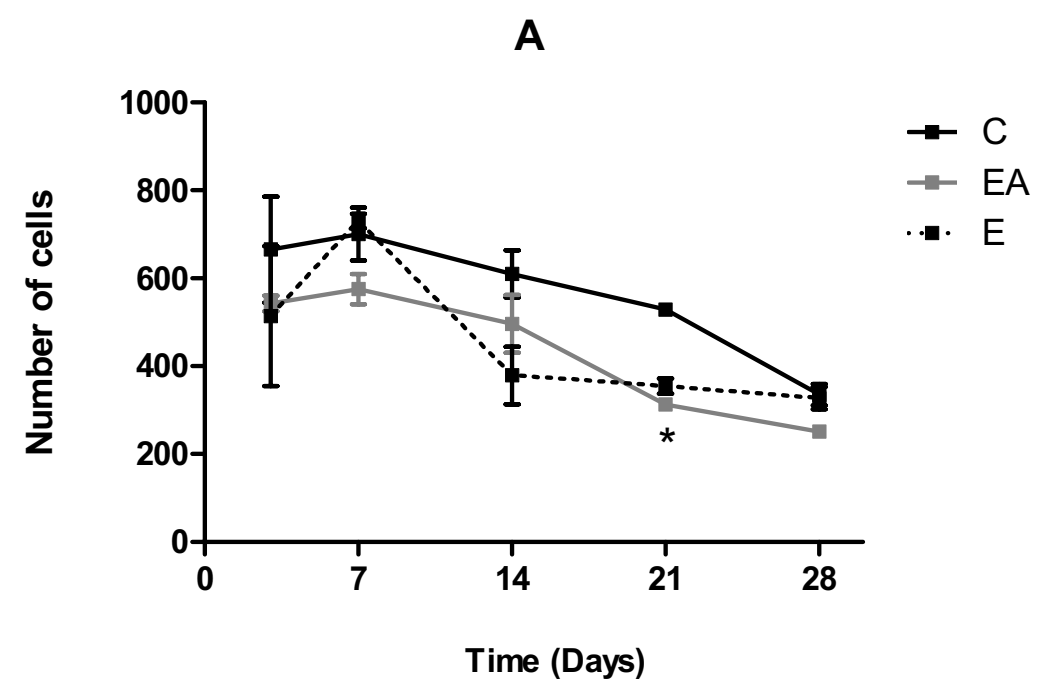

B

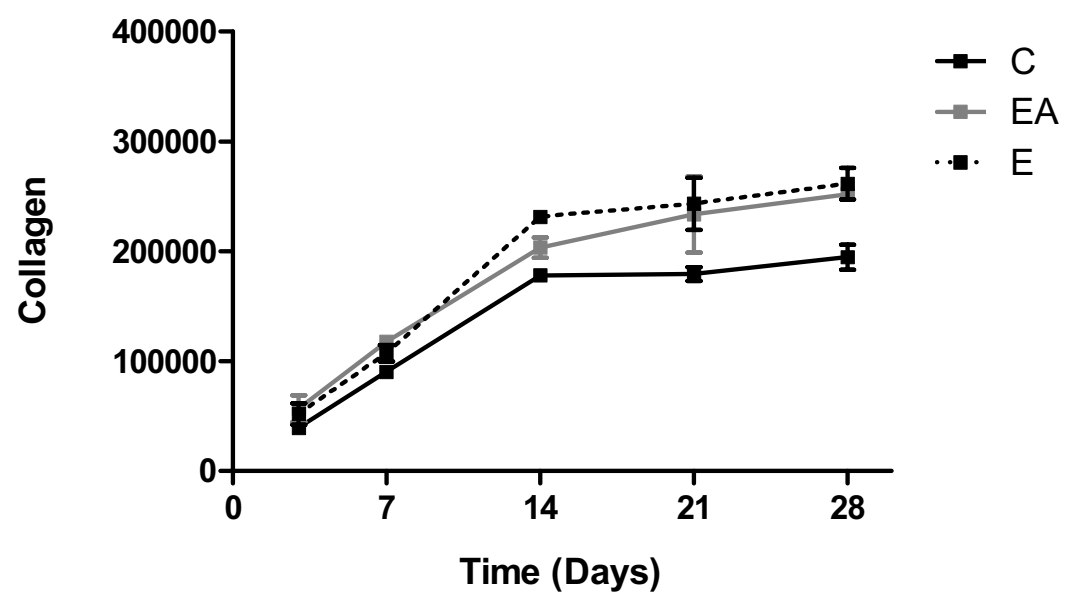

FIGURE 5 - Kinetics of inflammatory process (A) and collagen neoformation (B) in the rat's skin not treated $(\mathbf{C})$ and treated with soft lotion $\mathrm{O} / \mathrm{W}$ emulsion containing (EA) or not (E) allantoin. Results were expressed as mean \pm S.E.M. $\left({ }^{*} \mathrm{p} \leq 0.05\right)$. 


\section{Discussion}

\section{Planimetric analysis}

In 1910 Alexis Carrel introduced the use of measurement of changes on surface area, as an index of the frequency of wound contraction $^{14}$ and since that time, countless works have used this method in studies of wound healing ${ }^{15,16}$. However, in this work, only the planimetric analysis did not allow the identification of significant differences of the wound contraction profiles, regardless of pharmacological treatment used (Figure 2). As previously described, there was a significant increase only in the wound size on the 3rd post-operative day for the EA group. According to Cross et al. ${ }^{14}$ and Teo and Naylor ${ }^{17}$ the increase of the initial wound area occurs because of the centrifugal retraction of the wound edges and due to the tension of the surrounding elastic skin, loss of adherence to deep fascia and mobility of mouse skin. So, qualitative and quantitative microscopic analyses were carried out to identify the effective pharmacological response of allantoin and elucidate its wound healing action mechanism.

\section{Histological analysis}

For the histological analysis of tissue, several types of stain are employed. In this work, Hematoxylin-Eosin (HE), for general morphological analysis of tissues and Masson's Trichrome (TM), for observation of the connective tissue, were used in qualitative and quantitative analysis.

The Figure 2 shows the histological healing profile induced by allantoin, when compared to control groups. The histological profile observed on the 3rd post-operative day in the three groups studied (C, E and EA) was similar to the one observed by Simoes et al. ${ }^{18}$ and Grillo et al. ${ }^{19}$ in a wound healing study in pigs where a small, but measurable collagen amount was present in the wound on the 3rd and 4th days of analysis. This histological profile is characteristic of the initial phase of the wound healing process, when micro-circulatory and cell changes occur, presenting vasodilatation, increase of vascular permeability, edema and neutrophils and monocytes migration ${ }^{1,18,20,21}$. During this stage of wound healing some characteristics of the proliferation phase can also be observed, such as presence of fibroblasts and endothelial cells that produce the granulation tissue ${ }^{1,22}$. Additionally, the fibrin-leukocyte crusts were present in greater length in the wounds on the 7th day in all groups studied. This histological profile is characteristic of the two initial phases of the wound healing process, when vasodilatation, inflammatory exudates, many inflammatory cells, angiogenesis, fibroblasts and increased collagen deposition are usually observed. On the other hand, it was also already possible to identify on this 7th day, elements of the last phase of this process, characterized by synthesis, degradation and reorganization of collagen by fibroblasts. On the 14th day the healing process was advanced presenting reduction of the inflammatory process, reepithelization of the tissues and collagen deposition presenting more differentiate fibers. Sanchez Neto et al..$^{23}$ observed a high concentration of polymorphonuclear cells
(PMN) by the initial phase of the process, after which it decreased gradually, fact that was also observed in the present work. These events were characteristic of the maturation phase of the wound healing process, where the synthesis, degradation and reorganization of collagen by fibroblasts promote scar formation as the final result. Finally, on the 21st and 28th days, typical characteristics of a remodeling phase of the wound healing process were observed.

The inflammatory response is an important step of the wound healing process as it prepares the environment of the wound for the process of repairing. However, this stage should not be very intense, because an excessive inflammatory response can cause delay in wound healing, in addition of favoring the disturbance of balance between synthesis and degradation of collagen and promoting degradation of the matrix ${ }^{24}$.

Our results suggest that the allantoin modulates the inflammatory response (Figures 4 and 5A), possibly by inhibiting the chemotaxis of inflammatory cells in the site of the wound, thus preventing the release of reactive species responsible for the oxidative stress and tissue damage as proposed by Bradbury et al. ${ }^{25}$ in a study of pathogenesis of vascular diseases. On the other hand, the well formed collagen fibers observed in EA group by qualitative analysis could support the allantoin effectiveness in fibroblastic proliferation and synthesis of extracellular matrix during wound healing. The processes of synthesis, degradation and remodeling of collagen remained at a constant level after the 14th day post-operative in all groups, which may indicate that during this period there was a quantitative and qualitative protein balance due to the dual function of fibroblast, synthesis and reabsorption of collagen (Figure 5B).

Normally, the pharmaceutical formulations containing allantoin (Septalan ${ }^{\circledR}$, Alphosyl lotion ${ }^{\circledR}$ ) use the concentration around $2 \%$. In this work, the concentration of $5 \%$, was used aiming to ensure its effectiveness as wound healing, since allantoin is normally linked to other active substances in the commercial formulations and here it was used alone. The results showed that allantoin at 5\% in soft lotion $\mathrm{O} / \mathrm{W}$ emulsion has a wound healing effect when compared with the controls groups, however it is not as intense as described in literature. It must be remembered that, despite of extensive use in pharmaceutical and cosmetic preparations and the multiple bibliographic citations that refer to allantoin wound healing properties ${ }^{6,7}$, none of these studies showed, so far, the allantoin histological profile of the wound healing or its action mechanism. This work innovates by demonstrating, qualitatively and quantitatively (by morphometric analysis), the histological profile of wound healing process induced by allantoin.

\section{Conclusion}

This work show, for the first time, the histological wound healing profile induced by allantoin in rats, and demonstrated that it is able to ameliorate and fasten the reestablishment of the normal skin. 


\section{References}

1.Mondolin M, Bevilacqua RG. Cicatrização das feridas. Síntese das aquisições recentes. Rev Bras Clin Terap. 1985;14:208-13.

2.Gillitzer R, Goebeler M. Chemokines in cutaneous wound healing. J Leukoc Biol. 2001;69:513-21.

3. Martin P. Wound healing - aiming for perfect skin regeneration. Science. 1997;276:75-81.

4. Singer AJ, Clark RAF. Cutaneous wound healing. N Engl J Med. 1999;341(10):738-46.

5. Rahban SR, Garner WL. Fibroproliferative scars. Clin Plast Surg. 2003;30(1):77-89.

6. Saito ML, Oliveira F. Confrei: virtudes e problemas. Rev Bras Farmacogn. 1986;1:74-85.

7. Oliveira SM, Silva JBP, Hernandes MZ, Lima MCA, Galdino SL, Pitta IR. Structure, reactivity, and biological properties of hidantoines. Quim Nova. 2008;31(3):614-22.

8. Loots JM, Loots GP, Joubert WS. The effect of allantoin on cellular multiplication in degenerating and regeneration nerves. S Afr Med J. 1979;55(2):53-6.

9. Shestopalov AV, Shkurat TP, Mikashinovich ZI, Kryzhanovskaya IO, Bogacheva MA, Lomteva SV, Prokofev VN, Guskov EP. Biological functions of allantoin. Biol Bull. 2006;33:437-40.

10. Veraldi S, Menter A, Innocenti M. Treatment of mild to moderate seborrhoeic dermatitis with MAS064D (Sebclair), a novel topical medical device: results of a pilot, randomized, double-blind, controlled trial. J Eur Acad Dermatol Venereol. 2008;22(3):290-6.

11. European Medicines Agency. The European Agency for the Evaluation of Medical Products. Committee for Veterinary Medicinal Products. Allantoin. October, 2001.

12. Sekine T, Kojima K, Ota T, Matsumoto T, Yamamoto T, Maitani Y, Nagai T. Preparation and evaluation of shikonin ointment for wound healing. Effectiveness in an experimental wound healing model in rats. Pharma Sci. 1998;8:249-53.

13. Agren MS, Mertz PM, Franzén L. A comparative study of three occlusive dressing in the treatment of full-thickness wounds in pigs. J Am Acad Dermatol. 1997;36:53-8.

14. Cross SE, Naylor IL, Coleman RA, Teo TC. An experimental model to investigate the dynamics of wound contraction. Br J Plast Surg. 1995;48(4):189-97.
15. Branco-Neto MLC, Ribas-Filho JM, Malafaia O, Oliveira-Filho MA, Czeczko NG, Aoki S, Cunha R, Fonseca VR, Teixeira HM, Aguiar LRF. Avaliação do extrato hidroalcoólico de Aroeira (Schinus terebinthifolius Raddi) no processo de cicatrização de feridas em pele de ratos. Acta Cir Bras. 2006;21(2):17-22.

16. Garros IC, Campos ACL, Tâmbara EM, Tenório SB, Torres OJM, Agulham MA, Araújo ACF, Santis-Isolan PMB, Oliveira RM, Arruda ECM. Extract from Passiflora edulis on the healing of open wounds in rats: morphometric and histological study. Acta Cir Bras. 2006;21(3):55-65.

17. Teo TC, Naylor IL. Modifications to the rate of wound contraction by allopurinol. Br J Plast Surg. 1995;48(4):198-202.

18. Simões MJ, Cabral ACV, Boyaciyan K, Kulay JR, Sasso WS. Aspectos ultra-estruturais dos fibroblastos e dos macrófagos durante o processo de reparação da pele de ratos. Rev Paul Med. 1986;104:132-5.

19. Grillo HC, Watts GT, Gross J. Studies in wound healing: contraction and the wound contents. Ann Surg. 1958;148(2):143-52.

20. Kiritsy CP, Lynch AB, Lynch SE. Role of growth factors in cutaneous wound healing: a review. Crit Rev Oral Biol Med. 1993;4(5):729-60.

21. Rappolee DA, Patel Y, Jacobson K. Expression of fibroblast growth factor receptors in peri-implantation mouse embryos. Mol Reprod Dev. 1998;51(3):254-64.

22. Witte MB, Barbul A. General principles of wound healing. Surg Clin North Am. 1997;77(3):509-28.

23. Sanchez Neto R, Barone B, Tevês DC, Simões MJ, Novo NF, Juliano Y. Aspectos morfológicos e morfométricos da reparação tecidual de feridas cutâneas em ratos com e sem tratamento com solução de papaína a 2\%. Acta Cir Bras. 1993;8(1):18-23.

24. Ashcroft GS, Mills SJ, Ashworth JJ. Ageing and wound healing. Biogerontology. 2002;3:337-45.

25. Bradbury AW, Murie JA, Rucley CV. Role of the leucocyte in the pathogenesis of vascular disease. Br J Surg. 1993;80(12):1503-12.

\section{Acknowledgment}

We are grateful to the scholarship afforded by Ouro Preto Federal University (UFOP) to the first author.

\section{Correspondence:}

Neila Márcia Silva Barcellos

Rua Costa Sena, 171

35400-000 Ouro Preto - MG Brasil

Phone: (55 31)3559-1040

neila@ef.ufop.br

\section{How to cite this article}

Araújo LU, Grabe-Guimarães A, Mosqueira VCF, Carneiro CM, Silva-Barcellos NM. Profile of wound healing process induced by allantoin. Acta Cir Bras. [serial on the Internet] 2010 Sept-Oct;25(5). Available from URL: http://www.scielo.br/acb 